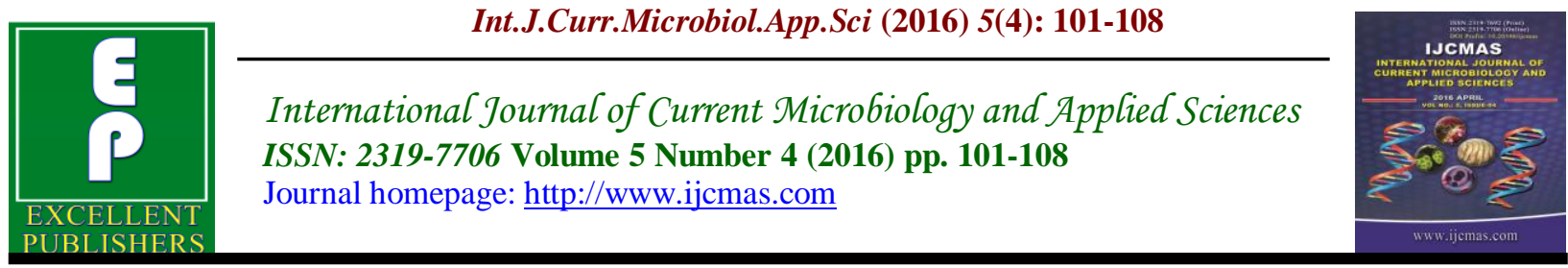

Original Research Article

http://dx.doi.org/10.20546/ijcmas.2016.504.014

\title{
Microbiological Profile in Urinary Tract Infections among Children in a Tertiary Care Center in Kumaun region, India
}

\author{
Umesh $^{1}$, Padmavati Bisht ${ }^{1,2} *$ and Sushma Tamta $^{3}$ \\ ${ }^{1}$ Department of Microbiology, Government Medical College, Haldwani, Nainital, India \\ ${ }^{2}$ Department of Biotechnology, Kumaun University Nainital, Bhimtal Campus, Bhimtal, India \\ ${ }^{3}$ Plant tissue culture laboratory, Department of Botany, Kumaun University Nainital, India \\ *Corresponding author
}

\section{Keywords \\ Urinary Tract Infections, Microbiological Profile, Escherichia coli Enterococcus sps.}

\section{Article Info}

Accepted: 09 March 2016 Available Online: 10 April 2016

\section{A B S T R A C T}

Urinary tract infection is one of the commonest bacterial infections encountered in daily clinical practice and a major problem that is frequently encountered by pediatrics healthcare providers. This study aimed to find bacterial profile of urinary tract infection (UTI) in children between less than 1 year to 15 years of age. This is a hospital based retrospective study conducted at Government Medical College, Haldwani over a period of January 2012 to March 2013. Clean catch mid-stream urine samples from 458 clinically suspected cases of urinary tract infections were processed as per standard procedures. Antimicrobial susceptibility test was performed for the isolated pathogens using Kirby-Bauer disk diffusion method according to Clinical and Laboratory Standards Institute guidelines. Among the 458 children, $75(16.37 \%)$ were found to be culture positive. Most common age group having culture positivity was 6-10 years (29.33\%). Present study showed that UTI is more common in boys (54.66\%) than in girls (45.33\%). The most common organism causing the urinary tract infection in this study was Escherichia coli $(\mathrm{n}=48,64 \%)$. Other were Enterococcus spp. $(\mathrm{n}=8,12 \%)$, Klebsiella spp. $(n=4$, $5.33 \%)$, Proteus spp. $(n=4,5.33 \%)$, Pseudomonas spp. $(n=3,4 \%)$, Coagulase negative staphylococcus $(n=2,2.66 \%)$, Citrobacter spp. $(n=2,2.66 \%)$, Acinetobacter spp. $(n=1,1.33 \%)$, MRCONS $(n=1,1.33 \%)$, and Staphylococcus aureus $(n=1,1.33 \%)$. E. coli showed $87.5 \%$ and $79.2 \%$ resistance to Ampicillin/sulbactum and Ciprofloxacin \& Levofloxacin respectively; while it showed less resistance (18.7\%) to Nitorfuratoin. Enterococcus spp. showed 88.88\% resistance to Norfloxacin and Ciprofloxacin.

\section{Introduction}

Urinary Tract Infection (UTI) implies the presence of actively multiplying organisms in the urinary tract (Singh and Madhup, 2013; Lambert and Coulthard, 2003) and it occurs in $3-5 \%$ of girls and $1 \%$ of boys during childhood, while it is more common in boys during the first year of life (Owa J.A., 2003). Every year about 250 million people worldwide are affected by UTIs. UTI is the third most common cause of 
admission to hospitals in India. It has been estimated that about 6 million patients per year are visited worldwide for UTI, out of which around 30,000 are treated in the wards (Bano et al., 2012). Urinary Tract Infection (UTI) is among the most common serious bacterial infections in infants and children, and is frequently missed, probably because of its non-specific presentation (Akash and Adarsh, 2013). It distresses the child and concerns the parents. It has a wide variety of clinical presentation, ranging from the asymptomatic presence of bacteria in the urine to potentially life-threatening infection of the kidney (Chang et al., 2006). Although, UTI is mainly due to ascending infection from the urethra, (Sharma et al., 2011) micro-organisms may reach the urinary tract by hematogenous or lymphatic routes as well. But ascending route accounts for almost $95 \%$ of cases of UTI (Goldman, 2000).

Common nonbacterial causes of UTI include hemorrhagic cystitis from adenovirus and Candida infection in immunocompromised individuals. Common bacterial pathogens include gram-negative species such as Escherichia coli, Klebsiella, Proteus, Enterobacter, Pseudomonas, and Serratia spp. and gram-positive organisms, including group B streptococci, Enterococcus sp., and Staphylococcus aureus (Zorc JJ, et al, 2005). Escherichia coli is the most frequent bacteria to cause UTI in infants and children. The diagnosis of UTI remains complicated by nonspecific symptoms and the difficulty in obtaining an uncontaminated urine specimen. The most recent guidelines issued by the American Academy of Pediatrics (1999) suggest that a UTI should be considered in infants and children who present with symptoms and they should also be evaluated with a urinalysis and urine culture (Johnson, 2003).

In recent years, widespread use of antibiotics has been resulted in an increasing incidence of antibiotic resistance among the urinary tract pathogens all over the world. Worldwide, emerging of antibiotic resistance is increasing among the urinary pathogens (Kahlmeter, 2003; Runehagen et al., 2002). The increase in resistance of microorganisms to antimicrobial agents, especially in hospitalized patients, demands rapid identification of the pathogens (Ashkenizi et al., Marray, 1990; Alon et al., 1987). The knowledge of etiology and antibiotic sensitivity and resistance pattern of the organisms causing urinary tract infection is essential (Akash et al., 2013). The aim of this study was to isolation and identification of uropathogens causing urinary tract infection and to obtain data on resistant pattern of these pathogens.

\section{Materials and Methods}

The study population was drawn from patients attending or admitted to pediatric department of Government Medical College, Haldwani from January 2012 to March 2013. Early morning mid-stream urine samples were collected by clean-catch method by using sterile wide mouthed glass bottles with screw cap tops. The specimens were transported to the bacteriology laboratory immediately or if there was a delay, refrigerated for 4 hours before processing. Isolation of uropathogens was performed by a surface streak procedure on Cysteine Lactose Electrolyte Deficient (C.L.E.D) medium with $4 \mathrm{~mm}$ sterilized inoculation loop, which can take about 0.01 $\mathrm{ml}$ of urine (one colony of a particular bacteria will be equal to 100 colony per ml of urine (Cheesbrough, 1984) in zigzag motion. All were then incubated at $37^{\circ} \mathrm{C}$ aerobically for 24 hours. Colonies were counted and multiplied by 1000 which results in $>10^{5}$ colony forming unit (CFU) / $\mathrm{ml}$ of urine sample. Bacterial count less than this were considered insignificant. Growth 
of 3 or more organisms was considered contamination. Subculture of the colonies was done on blood agar and MacConkey agar to characterize the isolate. Bacterial pathogens were identified by conventional biochemical methods according to standard microbiological techniques (Collee et al., 1996). For susceptibility testing MullerHinton agar plate was swabbed with the suspension using sterile cotton swab and the antibiotic discs were placed over the agar and left for 30 minutes for diffusion of the antibiotics in the disc. The zones of inhibition were then read as resistant and sensitive using calibrated ruler and compared with the standard chart (Baurer et al., 1966).

Antibiotics agents employed for susceptibility testing were Ampicillin/sulbactum, Ceftriaxone, cotrimoxazole, Gentamicin, Levofloxacin, Linezolid, Nitrofurantoin, Norfloxacin and Ciprofloxacin. All isolates were tested for antimicrobial susceptibility against different antibiotics using the disc diffusion method (Cheesbrough, 2000). Standard control strains of E. coli ATCC 11774, S.aureus ATCC43300, Enterococcus faecalis ATCC 51299, Klebsiella ATCC 13883, Pseudomonas aeruginosa ATCC 15442 and Proteus mirabilis ATCC 7490 were used during culturing and antibiotics susceptibility testing as a control throughout the study.

\section{Results and Discussion}

A total of 458 urine samples were collected from children with clinically suspected urinary tract infections, $255 \quad(55.67 \%)$ samples were from male patients and 203 $(44.32 \%)$ samples were from female patients. Out of which $75(16.37 \%)$ urine samples were identified positive as shown in Table 1.
Present study shows that UTI is more common in boys $(54.66 \%)$ than in girls $(45.33 \%)$. Majority of the cases were of less than 10 years of age. Maximum number of cases was seen in age group 6-10 years of age, where the percentage of male were $11(50 \%)$ and female were $11(50 \%$ ) respectively. The age and gender wise distribution of children from whom the urine samples were collected is shown in Table 2.

The most common organism causing the urinary tract infection in this study was Escherichia coli $(\mathrm{n}=48,64 \%)$. Other were Enterococcus spp. $(\mathrm{n}=8,12 \%)$, Klebsiella spp. $(n=4,5.33 \%)$, Proteus spp. $(n=4$, $5.33 \%)$, Pseudomonas spp. $(n=3,4 \%)$, Coagulase negative staphylococcus ( $n=2$, $2.66 \%)$, Citrobacter spp. $(n=2,2.66 \%)$, Acinetobacter spp. $(n=1,1.33 \%)$, MRCONS $(n=1,1.33 \%)$, and Staphylococcus aureus $(n=1,1.33 \%)$. E. coli (25 from male and 23 from female) and Enterococcus spp. (5 from male and 4 from female) were the most common microorganisms isolated from both male as well as female patients. Similarly $E$. coli and Enterococcus spp. were the most common isolates in all age group. Distribution of organisms isolated from urine samples were shown in figure 1.

Among the 62 gram-negative bacteria, E. coli showed $87.5 \%$ and $79.2 \%$ resistance to Ampicillin/sulbactum and Ciprofloxacin \& Levofloxacin respectively while it showed less resistance $18.75 \%$ to Nitorfuratoin. Pseudomonas spp., showed $100 \%$ resistance to Ampicillin /sulbactum, Cotrimoxazole, Ceftriaxone, Ceftriaxone/ sulbactum, Nitrofurantoin while less resistance to Levofloxacin. Citrobacter spp. showed $100 \%$ resistance to all drugs, and Acinetobacter spp. was fully sensitive to all drugs except to Ceftriaxone and Cotrimoxazole. 
Table.1 Distribution of Culture Positive and Culture Negative Samples

\begin{tabular}{|l|l|l|}
\hline Culture results & Sample & $\%(\mathbf{n = 4 5 8})$ \\
\hline Positive & 75 & $16.37 \%$ \\
\hline Negative & 383 & $83.63 \%$ \\
\hline Total & 458 & $100 \%$ \\
\hline
\end{tabular}

Table.2 Age and Gender Wise Distribution of Urinary Tract Infection

\begin{tabular}{|l|l|l|l|}
\hline Age (years) & Male & Female & Total \\
\hline$<1$ & $7(46.66 \%)$ & $8(53.33)$ & $15(20 \%)$ \\
\hline $1-5$ & $15(71.42)$ & $6(28.57 \%)$ & $21(28 \%)$ \\
\hline $6-10$ & $11(50 \%)$ & $11(50 \%)$ & $22(29.33 \%)$ \\
\hline $11-15$ & $8(47.05 \%)$ & $9(52.94 \%)$ & $17(22.66 \%)$ \\
\hline Total & $41(54.66 \%)$ & $34(45.33 \%)$ & $75(100 \%)$ \\
\hline
\end{tabular}

Table.3 Antibiotic Susceptibility of Gram-Negative Organisms

\begin{tabular}{|c|c|c|c|c|c|c|}
\hline \multirow[t]{2}{*}{ Antibiotics } & \multicolumn{6}{|c|}{$\%$ of isolates resistant to antibiotic } \\
\hline & $\begin{array}{l}\text { E. coli } \\
(n=48)\end{array}$ & $\begin{array}{l}\text { Klebsiella } \\
\text { spp. }(n=4)\end{array}$ & $\begin{array}{l}\text { Pr. } \\
\text { mirabilis } \\
(n=4)\end{array}$ & $\begin{array}{l}\text { Pseudomonas } \\
\text { spp. }(n=3)\end{array}$ & $\begin{array}{l}\text { Citrobacter } \\
\operatorname{spp} .(n=2)\end{array}$ & $\begin{array}{l}\text { Acinetobacter } \\
\operatorname{spp} .(n=1)\end{array}$ \\
\hline Ampicillin/sulbactum & $42(87.5 \%)$ & $3(75 \%)$ & $2(50 \%)$ & $3(100 \%)$ & $2(100 \%)$ & $0(0 \%)$ \\
\hline Ceftriaxone & $32(66.66 \%)$ & $4(100 \%)$ & $0(0 \%)$ & $3(100 \%)$ & $2(100 \%)$ & $1(100 \%)$ \\
\hline Ceftriaxone/sulbactum & $17(35.41 \%)$ & $2(50 \%)$ & $0(0 \%)$ & $3(100 \%)$ & $2(100 \%)$ & $0(0 \%)$ \\
\hline Cotrimoxazole & $29(60.41 \%)$ & $2(50 \%)$ & $4(100 \%)$ & $3(100 \%)$ & $2(100 \%)$ & $1(100 \%)$ \\
\hline Nitrofurantoin & $9(18.75 \%)$ & $3(75 \%)$ & $4(100 \%)$ & $3(100 \%)$ & $2(100 \%)$ & $0(0 \%)$ \\
\hline Norfloxacin & $39(81.25 \%)$ & $3(75 \%)$ & $1(25 \%)$ & $1(33.33 \%)$ & $2(100 \%)$ & $0(0 \%)$ \\
\hline Ciprofloxacin & $38(79.16 \%)$ & $3(75 \%)$ & $2(50 \%)$ & $2(66.66 \%)$ & $2(100 \%)$ & $0(0 \%)$ \\
\hline Levofloxacin & $38(79.16 \%)$ & $3(75 \%)$ & $0(0 \%)$ & $1(33.33 \%)$ & $2(100 \%)$ & $0(0 \%)$ \\
\hline
\end{tabular}


Table.4 Antibiotic Susceptibility of Gram-Positive Organisms

\begin{tabular}{|l|l|l|l|l|}
\hline \multirow{2}{*}{ Antibiotics } & \multicolumn{3}{|l|}{ \% of isolates resistant to antibiotic } \\
\cline { 2 - 5 } & $\begin{array}{l}\text { Enterococcus spp. } \\
(\mathbf{n = 9})\end{array}$ & $\begin{array}{l}\text { CONS spp. } \\
(\boldsymbol{n}=\mathbf{2})\end{array}$ & $\begin{array}{l}\text { MRCONS } \\
(\boldsymbol{n}=\mathbf{1})\end{array}$ & $\begin{array}{l}\text { S.aureus } \\
(\boldsymbol{n}=\mathbf{1})\end{array}$ \\
\hline Ampicillin/sulbactum & $7(77.77 \%)$ & $0(0 \%)$ & $1(100 \%)$ & $1(100 \%)$ \\
\hline Cotrimoxazole & $5(55.55 \%)$ & $0(0 \%)$ & $1(100 \%)$ & $1(100 \%)$ \\
\hline Norfloxacin & $8(88.88 \%)$ & $0(0 \%)$ & $1(100 \%)$ & $1(100 \%)$ \\
\hline Nitrofurantoin & $5(55.55 \%)$ & $0(0 \%)$ & $1(100 \%)$ & $1(100 \%)$ \\
\hline Ciprofloxacin & $8(88.88 \%)$ & $0(0 \%)$ & $1(100 \%)$ & $1(100 \%)$ \\
\hline Levofloxacin & $7(77.77 \%)$ & $0(0 \%)$ & $1(100 \%)$ & $1(100 \%)$ \\
\hline Cephoxitin & $5(55.55 \%)$ & $0(0 \%)$ & $1(100 \%)$ & $1(100 \%)$ \\
\hline Linezolid & $3(33.33 \%)$ & $0(0 \%)$ & $1(100 \%)$ & $1(100 \%)$ \\
\hline Cephalexin & $7(77.77 \%)$ & $1(50 \%)$ & $1(100 \%)$ & $1(100 \%)$ \\
\hline
\end{tabular}

CONS: Coagulase negative Staphylococci, MRCONS: Methcillin resistant Coagulase negative Staphylococci, S. aureus: Staphylococcus aureus, $\mathrm{n}=$ number of isolates

Figure.1 Distribution of Organisms Isolated from Urine Samples

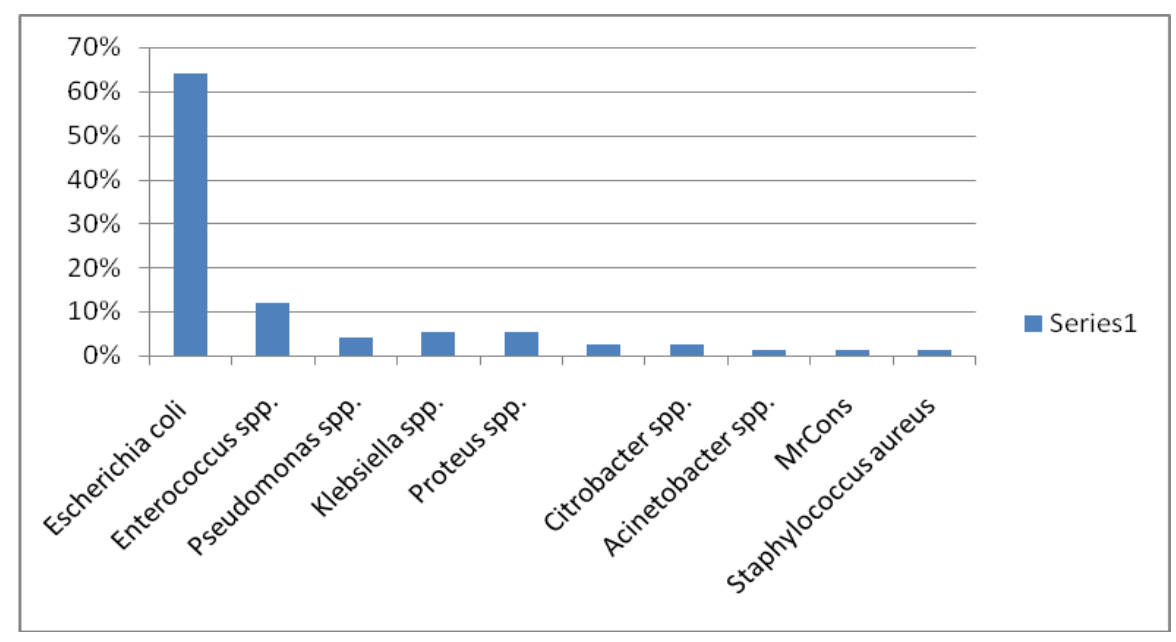

Among the gram-positive bacteria Enterococcus showed $88.88 \%$ resistance to Norfloxacin and Ciprofloxacin. MRCONS and S.aureus was found resistant to all drugs. Only CONS showed $100 \%$ sensitivity to all drugs. Table 3 and table 4 shows the Antibiotic resistance pattern of grampositive and gram-negative organisms respectively.

Urinary tract infection (UTI) is one of the commonest bacterial infections seen by Pediatricians in children. However, diagnosis remains a difficult task probably because its presentation is non-specific and similar to other common illnesses. Therefore, it is often missed diagnosis in children (Adedoyin et al., 2003; Owa et al., 1999).

The urinary culture positive rate was $16.37 \%$ in this study which was similar to rates of $16.2 \%$ Ranjbar et al., $19.3 \%$ Shreshtha et al., 18.49\% Raghubanshi et al., in previous studies. However another study from Nepal showed $28 \%$ of positivity rate 
out of 1878 study subjects (Runehagen, 2002). Another study done at KCH by G.K. Rai et al., found $28.6 \% 28 \%$ culture positive from 205 urine samples. In our present study culture positivity rate is less $(16.37 \%)$ than that of study done by GK. Rai et al., and K. Gautam et al., and may be attribute to sample size.

UTI is a common problem in children but the prevalence varies with in the age and sex of children it occurs in about one percent of boys and three to five percent of girls (Wald, 2004; Sherestha et al., 2005; Elder et al., 2007). However, in contrast to this, present study shows marginally higher positive rate among male children compared with female children (Male 56\% vs. Female 44\%). This could be due to the relatively more number of male children coming to the hospital and might have been attributed to the preference given to the male children in the Indian society (Pooja et al., 2014). Similarly, GK Rai et al., 2007 also observed higher positive rate among male children compared with female children (Male $51.7 \% \%$ and Female $48.3 \%$ ).

In this study Escherichia coli (64\%) was found to be the most common organism causing UTI in females as well as males this finding is very similar to Muhammad et al, 2009, Bosch et al., 2011; Nadir, 2010; Eshwarappa et al., 2011; Mumke et al., 2013; Ines et al., 2013. On the other hand present finding was lesser than the finding of GK et al (93.3\%), and higher than the findings of Godwin et al. (36.4\%), Ranjbar et al. (40\%), Taneja et al. (47.1\%), and Jha B K et al. (1.39\%). This variation can be due to age groups, congenital anomalies of urinary tract (Roberts, 1996).

Out of 62 gram-negative isolates, the four highest observed resistances were for Ampicillin /sulbactum 87.5\%, Norfloxacin
$81.25 \%$, Ciprofloxacin $79.16 \%$ and Levofloxacin $79.16 \%$ indicating over prescription of these drugs. The commonly used antibiotics such as Nitrofurantoin, Ampicillin/sulbactum and Co-trimoxazole were poorly effective against majority of the organisms isolated in this study. High percentage of isolates showed resistance to sulfa drugs such as Cotrimoxazole that is line with previous finds (Tambekar et al., 2005). Antibiotic sensitivity and resistance pattern vary over time and places. The study showed a high resistance to antimicrobials like Ampicillin, Co-trimoxazole, Ciprofloxacin, Norfloxacin; could be these antibiotics were in general use for a long period. This study provides a glimpse of emerging antimicrobial resistance pattern. This type of study should be done periodically to assess the pattern of microorganisms causing UTI and their antimicrobial susceptibility, which will guide in selection of antibiotics for the empiric treatment.

\section{References}

Adedoyin, O.T., Oyeyemi, B.O., Aiyedehin, O.V. 2003. Screening of febrile children on hospital admission for urinary tract infections (UTI). African J. Clin. Experimental Microbiol., 4(1): 56-62.

Akash, S., Adarsh, E. 2014. ClinicoMicrobiological Profile of UTI in Children less than 10 years in Department of Pediatrics in Tertiary Care Centre. J. Evol. Med. Dent. Sci., Vol. 3, Issue 15, April 14; Page: 38743882 ,

DOI: 10.14260/jemds/2014/2370.

Alon, U., Davidai, G., Berant, M., Merzbach, D. 1987. Five-year survey of changing patterns of susceptibility of bacterial uropathogens to trimethoprim- sulfamethoxazole and 
other antimicrobial agents. Antimicrob. Agents and Chemother., 31(1): 126128.

Ashkenazi, S., Even-Tov, S.M.A.D.A.R., Samra, Z., Dinari, G. 1991. Uropathogens of various childhood populations and their antibiotic susceptibility. The Pediatric Infect. Dis. J., 10(10): 742-745.

Bano, K., Khan, J., Begum, R.H., Munir, S., Akbar, N., Ansari, J.A., Anees, M. 2012. Patterns of antibiotic sensitivity of bacterial pathogens among urinary tract infections (UTI) patients in a Pakistani population. Afri. J. Microbiol. Res., 6(2): 414-20.

Bauer, A.W., Kirby, W.M.M., Sherris, J.C.T., Turck, M. 1966. Antibiotic susceptibility testing by a standardized single disk method. American J. Clin. Pathol., 45(4): 493.

Bosch, F.J., Van Vuuren, C., Joubert, G. 2011. Antimicrobial resistance patterns in outpatient urinary tract infections: the constant need to revise prescribing habits. SAMJ: South African Med. J., 101(5): 328-331.

Chang, S.L., Shortliffe, L.D. 2006. Pediatric urinary tract infections. Pediatric Clin. North America, 53(3): 379-400.

Cheesbrough, M. 2000. District Laboratory Practice in Tropical Country. Part2. 2nd ed. Cambridge University Press: London, 132-1342.

Collee, J.G., Miles, R.S., Watt, B. 1996. Tests for identification of bacteria, Mackie and McCartney practical, Med. Microbiol., 14: 131-149.

Elder, J.S. 2007. Urinary tract infections. In: Kliegman R. M., Behrman R.E., Jenson H.B., Stanton B.E., Nelson Textbook of Pediatrics. Philadelphia: Saunders, 2223-8.

Eshwarappa, M., Dosegowda, R., Aprameya, I.V., Khan, M.W., Kumar, P.S., Kempegowda, P. 2011. Clinico- microbiological profile of urinary tract infection in south India. Indian $J$. Nephrol., 21(1): 30-36.

Goldman, M., Lahat, E., Strauss, S., Reisler, G., Livne, A., Gordin, L., Aladjem, M. 2000. Imaging after urinary tract infection in male neonates. Pediatrics, 105(6): 1232-1235.

Johnson, J.R. 2003. Microbial virulence determinants and the pathogenesis of urinary tract infection. Infect. Dis. Clin. North America, 17(2): 261-278.

Kahlmeter, G. 2003. An international survey of the antimicrobial susceptibility of pathogens from uncomplicated urinary tract infections: the ECO. SENS Project. $J$ Antimicrob. Chemother., 51(1): 69-76.

Lambert, H., Coulthard, M. 2003. The child with urinary tract infection. Clinical Paediatric Nephrol., 3: 197-225.

Linhares, I., Raposo, T., Rodrigues, A., Almeida, A. 2013. Frequency and antimicrobial resistance patterns of bacteria implicated in community urinary tract infections: a ten-year surveillance study (2000-2009). BMC Infect. Dis., 13(1): 1.

Muoneke, V.U., Ibekwe, M.U., Ibekwe, R.C. 2013. Childhood urinary tract infection in Abakaliki: Etiological organisms and antibiotic sensitivity pattern. Annals of Med. Health Sci. Res., 2(1): 29-32.

Murray, B.E. 1989. Problems and mechanisms of antimicrobial resistance. Infect. Dis. Clin. North America, 3(3): 423-439.

Owa, J.A. 1999. Urinary tract infections in children. In: Azubuike JC, Nkangineme K. E., editors. Paediatrics and Child Health in a Tropical Region. Owerri: African Educational services, pp. 480-1.

Patel, P., Garala, R.N. 2014. Bacteriological profile and antibiotic susceptibility 
pattern (antibiogram) of urinary tract infections in paediatric patients. J. Res. Med. Dent. Sci., 2(1): 20-23.

Raghubanshi, B.R., Shrestha, D., Chaudhary, M., Karki, B.M.S., Dhakal, A.K. 2014. Bacteriology of urinary tract infection in pediatric patients at KIST Medical College Teaching Hospital. J. Kathmandu Med. Coll., 3(1): 21-25.

Ranjbar, R.E.Z.A., Haghi-Ashtiani, M.T., Jafari, N.J., Abedini, M. 2009. The prevalence and antimicrobial susceptibility of bacterial uropathogens isolated from pediatric patients. Iranian J. Public Health, 38(2): 134-8.

Roberts, J.A. 1996. Factors predisposing to urinary tract infections in children. Pediatric Nephrol., 10(4): 517-522.

Runehagen, R., Kahlmeter, G. 2002. A 10year study of the consumption of quinolones, trimethoprim and mecillinam in relation to the development of antimicrobial resistance in a large number of species. Clin. Microbiol. Infection, 8(Supplement 1): 64.

Shaikh, N. 2010. Acute urinary tract infection in infants and young children. Canadian Med. Assoc. J., 182(8): 800-801.

Sharma, A., Shrestha, S., Upadhyay, S., Rijal, P. 2011. Clinical and bacteriological profile of urinary tract infection in children at Nepal Medical
College Teaching Hospital. Nepal Med. Coll. J., 13(1): 24-26.

Shrestha, B., Basnet, R.B., Shrestha, P., Shahi, P. 2005. Prevalence of urinary tract infection in female patients attending Kathmandu Model Hospital. J. Nepal Assoc. Med. Lab. Sci., 7: 1014.

Singh, S.D., Madhup, S.K. 2013. Clinical profile and antibiotics sensitivity in childhood urinary tract infection at Dhulikhel Hospital. Kathmandu Univ. Med. J. (KUMJ), 11(44): 319.

Tambekar, D.H., Dhanorkar, D.V. 2005. The prevalence and antibiogram of potential bacterial pathogens in clinical specimens. In 46th Annual Microbiologists of India, Osmania University, Hyderabad.

Taneja, N., Chatterjee, S.S., Singh, M., Singh, S., Sharma, M. 2010. Pediatric urinary tract infections in a tertiary care center from north India. The Indian J. Med. Res., 131: 101-05.

Wald, E.R. 2004. Evaluating urine cultures in young infants. The Pediatric Infect. Dis. J., 23(4): 376-377.

Younas, M., Khawaja, T.M., Talaat, A. 2009. Pattern of antibiotic resistance in urinary isolates in children: what could be the empirical treatment. $J$. Postgrad. Med. Institute, 23(1): 40-45.

Zorc, J.J., Kiddoo, D.A., Shaw, K.N. 2005. Diagnosis and management of pediatric urinary tract infections. Clin. Microbiol. Rev., 18(2): 417-422.

\section{How to cite this article:}

Umesh, Padmavati Bisht and Sushma Tamta. 2016. Microbiological Profile in Urinary Tract Infections among Children in a Tertiary Care Center in Kumaun region, India. Int.J.Curr.Microbiol.App.Sci. 5(4):101-108. doi: http://dx.doi.org/10.20546/ijcmas.2016.504.014 